\title{
AWARENESS, PERCEPTIONS AND DENTAL SERVICES UTILIZATION BY PATIENTS A TERTIARY CARE CENTRE DURING COVID-19 PANDEMIC
}

\author{
All India Institute of Medical Sciences, Centre for Dental Education and Research, New Delhi
}

\begin{abstract}
BACKGROUND. COVID -19 pandemic has imposed multiple questions and consideration in the minds of the patients and dental professionals. The understanding of patient's perceptions and dental services utilization can aid in modifying the pre-existing dental practices. The aim of the present study was to assess the awareness, perceptions and dental services utilization by patients visiting a tertiary care centre during COVID-19,

METHODOLOGY. A cross-sectional study on 437 patients was carried using a validated questionnaire consisting of 22 questions on three domains. Strict sterilization protocol and infection control measures were practiced to avoid any contact between the investigator and the patient.

RESULTS. Patients were aware of COVID -19 pandemic and were willing (76.7\%) to inculcate preventive practices even post-pandemic. Concerns regarding the spread of infection (37.3\%) and hygiene/cleanliness (28.6\%) were most commonly reported. Patients visited the dental centre primarily for emergency management and preferred their queries being solved on the phone.

CONCLUSION. Patients had a positive outlook towards visiting the dental centre for treatment in the near future and did not report any anxiety before visiting a dental centre.
\end{abstract}

Key words: coronavirus, pandemics, perception, dental service, hospital

\section{INTRODUCTION}

Coronaviruses a huge virus family is associated with disease in animals or humans. Coronaviruses affects humans with infections ranging from the common cold to dreadful diseases. (1) The recently discovered coronavirus causes COVID-19 infection which was unknown before the outbreak started in Wuhan, China, on $31^{\text {st }}$ December 2019 (1)

This outbreak was announced as a Public Health Emergency on 30 January 2020 by the World Health Organization (WHO); however, pertaining to over 118,000 cases in more than 110 countries and surrounding areas across the globe COVID-19 was declared as a pandemic by WHO on March 11. [2], [3] The first case of COVID-19 pandemic emerged in India on $30^{\text {th }}$ January 2020 in Kerala state (4),

A nationwide campaign of lockdown was initiated by the Government of India on $24^{\text {th }}$ of March 2020, initially for 21 days thereby curbing daily operations of the whole 130 crores residents of India as a precautionary step against the COVID-19. It started after a 14-hour voluntary mass curfew followed on by execution of regulatory series in the various COVID 19 affected states (5). Because of continuous rise in the number of coronavirus cases the lockdown was further extended till the end of May in different phases. The lockdown restrictions were subsequently lifted in a sequential manner from then onwards and services were resumed in a phased manner (5).

The routine healthcare services in India were also hampered during this lockdown with medical and dental professionals providing only emergency treatment procedures. The Dental Council of India issued a detailed advisory on May 7, which categorized dental issues as an emergency, urgent and advised against performing any procedures that involve use of aerosols, essentially ruling out root canal treatment, implants and most other surgical procedures (6).

Despite the large scale transmission of COVID-19, demand for dental treatment decreased only a little during the pandemic. The need for provision of urgent dental treatment and care was always considered essential (7).

The changing global scenario in addition to the demand for safe dental care has imposed multiple questions and consideration in the minds of the patients and dental professionals. An understanding of patient's perceptions and dental services utilization can not only aid in modifying the pre-existing dental

(C) National Institute of Public Health - National Institute of Hygiene / Narodowy Instytut Zdrowia Publicznego - Państwowy Zakład Higieny 
practices but can also lay down the path in determining the pivotal changes required in dental settings during and post COVID -19 eras.

The present study was thus carried out to assess the perceptions and dental service utilization of the patients visiting a tertiary care centre. Additionally, the study also assessed the awareness among the patients regarding COVID-19 pandemic.

\section{METHOD}

A questionnaire-based cross-sectional study was carried out among the patients visiting the dental centre of All India Institute of Medical Sciences (AIIMS), New Delhi. Patients willing to participate and intellectually and physically capable of responding to the questionnaire were included, whereas the patients who did not wish to cooperate with the study protocol were excluded from the present study.

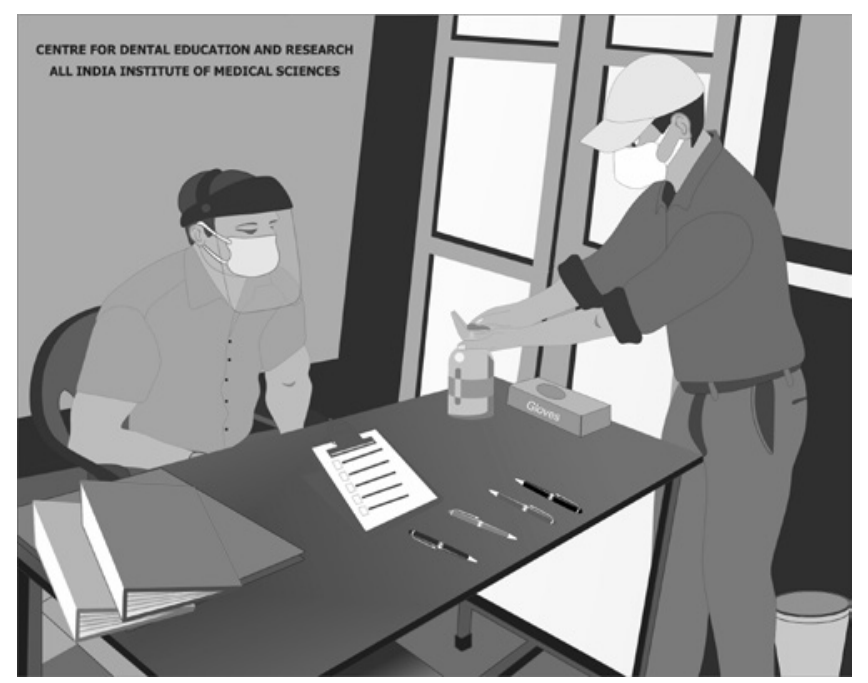

Fig. 1

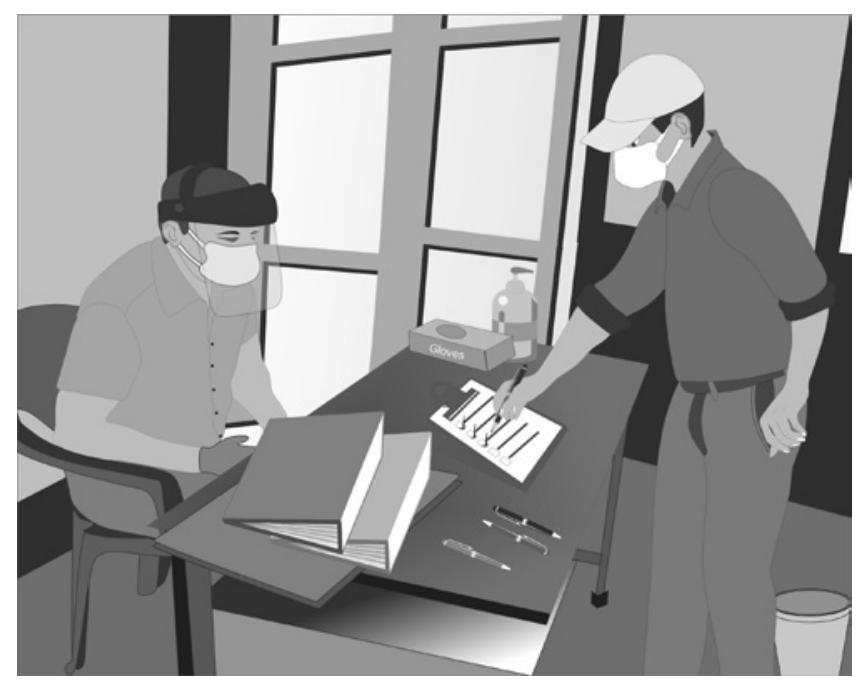

Fig. 2
Ethical approval to conduct the study was taken from the Institutional Review Board of All India Institute of Medical Sciences, New Delhi (IEC742/07, RP -16/2020). Written informed consent for participation was obtained. Strict sterilization protocol and infection control measures were practiced to avoid any contact between the investigator and the patient (Fig. 1 and 2). This study was carried out for one month (July 2020) after the strict lockdown phase was over and sequential unlocking of the regular health care services started in India. The total patients visiting the tertiary centre study duration were 546 of which 437 patients (response rate $80 \%$ ) participated in the study. The non respondents lacked the capacity to cooperate with the study protocol or did not provide consent to participate in the study. The study sample thus comprised of conveniently selected 437 patients visiting the Centre for Dental Education and Research (CDER), AIIMS New Delhi.

\section{DEVELOPMENT OF QUESTIONNAIRE}

A questionnaire for awareness related to COVID-19, perceptions and dental services utilization was used in this study. Initial preparation of the questionnaire was done in English; translated into Hindi language and further back-translated into English by professional translators to check for the efficiency and correctness of the information conveyed.

The development of the questionnaire followed the sequential steps starting with the identification of three domains: Awareness, Perception and Dental Service Utilization. The questionnaire was designed in accordance with the identified domains using relevant literature as well as upon the opinions based on the professional expertise of the authors. The first part of the questionnaire included socio-demographic details like age, gender, level of education and occupation. The other parts consisted of multiple-choice questions and a picture-based question based upon the identified domains. The pictorial question was incorporated in accordance to the thematic appreciation test in which the respondents were asked to explain the picture about what they think is happening in it. ${ }^{[8]}$ The results of the pictorial question were quantified into correct and incorrect response for analysis.

The awareness domain consisted of 10 questions whereas the perceptions and dental service utilization consisted of 15 questions. Thus a total of 25 item pool was developed by a group of four dental professionals. The group then discussed the items and eliminated three items one from awareness and two from utilization domain which was not found to be relevant.

The assessment of questionnaire validity qualitatively was carried out by evaluating the content 
and face validity. The questionnaire was presented to six experts from public health dentistry, community medicine, orthodontics, oral surgery and biostatistics that were acquainted with the topic. Based on the professional judgment necessary changes were made. The quantitative assessment of validation was done using the content validity ratio (9).

The final questionnaire consisted of three sections. The demographic characteristics were assessed in the first section and the final questionnaire comprised of 22 questions with nine questions evaluating the patient's awareness regarding Covid-19 pandemic and 13 questions assessing the patient's perceptions and dental services utilization. The questions on dental service utilization and perceptions consisted of reasons of visiting the dental centre, associated anxiety, perceived change in the dental services postpandemic and effectiveness of teleconsultation as a means of rendering dental services post lockdown.

Test-retest reliability was assessed by determining the level of agreement between initial scores and scores at the second assessment. No items were deleted/ modified at this stage.

A pilot study was conducted among 20 patients who were divided into two groups of ten patients each. Data collection in the first group was done using Google forms via a tablet whereas in the other group it was done using the paper format. The pilot study was conducted to determine the feasibility of the study and the acceptability of the recording format for the present study. The paper format was better accepted by the patients in spite of following all the appropriate infection control protocols in both the methods. Data collection by paper format was thus adopted in this study. The results of the pilot study were not included in the final analysis.

Table I: Descriptive characteristics of study patients

\begin{tabular}{|c|c|c|}
\hline Characteristics & Categories & $\mathrm{N}(\%)$ \\
\hline \multirow{2}{*}{ Gender } & Male & $204(46.7)$ \\
\cline { 2 - 3 } & Female & $233(53.3)$ \\
\hline \multirow{4}{*}{ Level of Education } & Primary & $49(11.2)$ \\
\cline { 2 - 3 } & Secondary & $142(32.5)$ \\
\cline { 2 - 3 } & Undergraduate & $144(33.0)$ \\
\cline { 2 - 3 } & Postgraduate & $78(17.8)$ \\
\cline { 2 - 3 } & PhD & $9(2.1)$ \\
\cline { 2 - 3 } & Other & $15(3.4)$ \\
\hline \multirow{4}{*}{ Occupation } & Student & $174(39.8)$ \\
\cline { 2 - 3 } & Employed & $128(29.3)$ \\
\cline { 2 - 3 } & Not employed & $70(16.0)$ \\
\cline { 2 - 3 } & & $65(14.8)$ \\
\hline
\end{tabular}

The data collected was entered in Microsoft Excel and subjected to statistical analysis using Statistical Package for Social Sciences (IBM Corp., Armonk, N.Y., USA Version 20). The level of significance was fixed at $5 \%$ and $\mathrm{p} \leq 0.05$ was considered statistically significant. Kolmogorov- Smirnov test and ShapiroWilks test were employed to test the normality of data. Chi-square test was performed for quantitative variables.

\section{RESULTS}

The mean age of the patients in this study was found to be $31.74 \pm 14.79$ years. Females $(52.7 \%)$ outnumbered male patients (47.3\%) and of the 437 patients assessed in the present study majority of patients were students $(39.8 \%)$ with the undergraduate level of education (33.0\%) (Tab, I).

Patients reported gathering information about COVID-19 from more than one medium; however, television was the single major source of information about COVID- 19. Majority of the patients in the present study were aware of the common symptoms, most affected age group and primary mode of transmission of COVID -19; however, were unable to identify (58.4\%) the violation of the COVID-19 norms when recorded via a picture based question. In our study, $81 \%$ of the patients avoided social events in this current pandemic whereas three/fourth $(74.4 \%)$ of the patients felt that the pandemic will be controlled eventually. Patients were more willing (81\%) to visit hospitals for dental services rather general health services and were willing $(76.7 \%)$ to inculcate preventive practices in routine life post-pandemic (Tab,II).

Assessment of the perceptions and dental service utilization by the patients in the present study revealed that majority of the patients did not self-report 
Table II: General awareness about COVID-19 among the patients visiting the center

\begin{tabular}{|c|c|c|}
\hline Questions & Options & $\mathrm{N}(\%)$ \\
\hline \multirow{7}{*}{ Major source of information about COVID 19} & Social Media & $79(18.1)$ \\
\hline & Newspaper & $30(6.9)$ \\
\hline & Television & $94(21.5)$ \\
\hline & Government Websites & $22(5.0)$ \\
\hline & AarogyaSetu & $41(9.4)$ \\
\hline & Other & $5(1.1)$ \\
\hline & More than one option & $166(38)$ \\
\hline \multirow{5}{*}{ The most common symptoms of COVID 19} & Fever, Dry Cough, Tiredness & $316(72.3)$ \\
\hline & Pain & $10(2.3)$ \\
\hline & Body ache & $8(1.8)$ \\
\hline & Sore throat & $20(4.6)$ \\
\hline & More than one option & $83(19)$ \\
\hline \multirow{5}{*}{ Age group more likely to develop serious illness } & Children & $30(6.8)$ \\
\hline & Young Adults & $12(2.7)$ \\
\hline & Older People & $190(43.5)$ \\
\hline & All of the above & $126(28.8)$ \\
\hline & More than one option & $79(18.1)$ \\
\hline \multirow{5}{*}{ Primary mode of transmission of COVID- 19} & Serum & $30(6.9)$ \\
\hline & Saliva & $41(9.4)$ \\
\hline & Blood & $21(4.8)$ \\
\hline & Respiratory Droplets & $308(70.5)$ \\
\hline & More than one option & $37(8.5)$ \\
\hline \multirow{3}{*}{ Do you think COVID 19 pandemic will be controlled eventually? } & Yes & $325(74.4)$ \\
\hline & No & $33(7.6)$ \\
\hline & Maybe & $79(18.0)$ \\
\hline \multirow{3}{*}{ Have you avoided social events due to current pandemic? } & Yes & $354(81)$ \\
\hline & No & $45(10.3)$ \\
\hline & Sometimes & $38(8.7)$ \\
\hline \multirow{3}{*}{$\begin{array}{l}\text { Do you wish to inculcate preventive practices in your routine life } \\
\text { post COVID } 19 \text { ? }\end{array}$} & Yes & $335(76.7)$ \\
\hline & No & $52(11.9)$ \\
\hline & Unsure & $50(11.4)$ \\
\hline \multirow{4}{*}{$\begin{array}{l}\text { Type of services preferred during hospital visiting in time of } \\
\text { pandemic }\end{array}$} & General Health Services & $97(22.2)$ \\
\hline & Dental Services & $181(41.4)$ \\
\hline & Both & $91(20.8)$ \\
\hline & None & $68(15.5)$ \\
\hline \multirow{2}{*}{ Awareness about COVID- 19 norms violation } & Yes & $182(41.6)$ \\
\hline & No & $255(58.4)$ \\
\hline
\end{tabular}

deterioration in oral health or anxiety signs before visiting a dental centre; however, we're concerned about safety measures $(54.9 \%)$ before visiting the dental centre. Concerns regarding the spread of infection (37.3\%) and hygiene/cleanliness (28.6\%) were most commonly reported by the patients. Amongst the various mode of registration assessed mobile application $(27.2 \%)$ was considered as the most preferred mode of registration whereas on spot in queue $(13 \%)$ registration was considered as the least preferred mode when compared with the website, telephonic/oncall modes of registration. Emergency treatment/pain (33.6\%) was reported as the chief reason for visiting the dental centre in this study.

Majority of the patients were not sure whether COVID infection can spread during dental treatment and did not think that the PPE kits can create hindrance in communication during the dental procedure. On one side patients preferred getting their dental queries solved on phone as compared to the visit at the clinic; 
however, on the other, were also not hesitant in visiting a dental care centre for routine dental treatment in the near future. Patients felt that teleconsultation can serve as an effective means of providing dental care postCOVID 19 (Tab. III).
Gender wise comparative evaluation in our study revealed a significant difference between males and females only for question related to the most concerning aspect before visiting a dental centre. No significant difference concerning gender was seen among the patients for knowledge or dental service utilization (Tab.IV).

Table III: Perceptions and Dental service utilization aspects among the patients visiting the centre during pandemic

\begin{tabular}{|c|c|c|}
\hline \multirow{3}{*}{$\begin{array}{l}\text { Deterioration in oral health during lockdown and COVID- } 19 \\
\text { pandemic }\end{array}$} & Yes & $91(20.8)$ \\
\hline & No & $296(67.7)$ \\
\hline & Maybe & $50(11.4)$ \\
\hline \multirow{3}{*}{$\begin{array}{l}\text { Anxiety signs like numbness/tingling, dizziness, nervousness } \\
\text { before visiting a dental centre }\end{array}$} & Yes & $39(8.9)$ \\
\hline & No & $381(87.2)$ \\
\hline & Maybe & $17(3.9)$ \\
\hline \multirow{3}{*}{$\begin{array}{l}\text { Concerns about safety measures visiting the dental centre during } \\
\text { COVID } 19 \text { pandemic }\end{array}$} & Yes & $241(54.9)$ \\
\hline & No & $151(34.6)$ \\
\hline & Maybe & $45(10.3)$ \\
\hline \multirow{5}{*}{ If yes, most concerned aspect before visiting a dental centre } & Hygiene/ Cleanliness & $125(28.6)$ \\
\hline & Large number of people & $58(13.3)$ \\
\hline & Dental Treatment & $37(8.5)$ \\
\hline & Spread of infection & $163(37.3)$ \\
\hline & More than one options & $54(12.3)$ \\
\hline \multirow{3}{*}{ Awareness of different methods of registration at the dental centre } & Yes & $290(66.4)$ \\
\hline & No & $94(21.5)$ \\
\hline & Maybe & $53(12.1)$ \\
\hline \multirow{5}{*}{ If yes, preferred mode of registration } & Mobile Application & $119(27.2)$ \\
\hline & On spot in queue & $57(13.0)$ \\
\hline & Website of dental centre & $85(19.5)$ \\
\hline & Telephonic/On call & $113(25.9)$ \\
\hline & More than one options & $63(14.4)$ \\
\hline \multirow{5}{*}{ Chief Complaint/ Reason for visiting the dental centre } & Routine OPD & $134(30.7)$ \\
\hline & Emergency Treatment/Pain & $147(33.6)$ \\
\hline & Trauma/ Fracture & $19(4.3)$ \\
\hline & Follow up & $108(24.7)$ \\
\hline & Any other & $29(6.6)$ \\
\hline \multirow{3}{*}{$\begin{array}{l}\text { Do you think COVID infection can spread during dental } \\
\text { treatment? }\end{array}$} & Yes & $168(38.4)$ \\
\hline & No & $94(21.5)$ \\
\hline & Maybe & $175(40.1)$ \\
\hline \multirow{3}{*}{$\begin{array}{l}\text { Do you think you can wait for long duration during the dental } \\
\text { treatment procedures at dental centres? }\end{array}$} & Yes & $159(36.4)$ \\
\hline & No & $177(40.5)$ \\
\hline & Maybe & $101(23.1)$ \\
\hline \multirow{3}{*}{$\begin{array}{l}\text { Do you think the PPE kits can create hindrance in communication } \\
\text { during dental procedure? }\end{array}$} & Yes & $87(19.9)$ \\
\hline & No & $225(51.5)$ \\
\hline & Maybe & $125(28.6)$ \\
\hline \multirow{3}{*}{$\begin{array}{l}\text { Would you prefer your dental queries being solved via phone as } \\
\text { compared to your visit at the dental centre? }\end{array}$} & Yes & $202(46.2)$ \\
\hline & No & $129(29.5)$ \\
\hline & Maybe & $106(24.3)$ \\
\hline
\end{tabular}


Do you feel teleconsultation can serve as effective means of providing dental care post COVID 19?

Do you plan to visit a dental centre for routine dental treatment in near future?

\begin{tabular}{|c|c|}
\hline Yes & $281(64.3)$ \\
\hline No & $156(35.7)$ \\
\hline Yes & $316(72.3)$ \\
\hline No & $27(6.2)$ \\
\hline Maybe & $94(21.5)$ \\
\hline
\end{tabular}

Table IV: Comparative evaluation of Gender with awareness, perceptions and dental service utilization by study patients

\begin{tabular}{|c|c|c|c|c|}
\hline Questions & Options & $\begin{array}{c}\text { Male } \\
\mathrm{N}\end{array}$ & $\begin{array}{l}\text { Female } \\
\mathrm{N}\end{array}$ & $P$ value \\
\hline \multirow{7}{*}{$\begin{array}{l}\text { Major source of information about } \\
\text { COVID } 19\end{array}$} & Social Media & 41 & 38 & \multirow{7}{*}{.206} \\
\hline & Newspaper & 9 & 21 & \\
\hline & Television & 45 & 49 & \\
\hline & Government Websites & 13 & 9 & \\
\hline & AarogyaSetu & 17 & 24 & \\
\hline & Other & 4 & 1 & \\
\hline & More than one option & 75 & 91 & \\
\hline \multirow{5}{*}{$\begin{array}{l}\text { The most common symptoms of COVID } \\
19\end{array}$} & Fever, Dry Cough, Tiredness & 149 & 167 & \multirow{5}{*}{.563} \\
\hline & Pain & 7 & 3 & \\
\hline & Body ache & 4 & 4 & \\
\hline & Sore throat & 8 & 12 & \\
\hline & More than one option & 36 & 47 & \\
\hline \multirow{5}{*}{$\begin{array}{l}\text { Age groupmore likely to develop serious } \\
\text { illness }\end{array}$} & Children & 19 & 11 & \multirow{5}{*}{.333} \\
\hline & Young Adults & 4 & 8 & \\
\hline & Older People & 87 & 103 & \\
\hline & All of the above & 61 & 65 & \\
\hline & More than one option & 33 & 46 & \\
\hline \multirow{5}{*}{$\begin{array}{l}\text { Primary mode of transmission of } \\
\text { COVID- } 19\end{array}$} & Serum & 15 & 15 & \multirow{5}{*}{.817} \\
\hline & Saliva & 19 & 22 & \\
\hline & Blood & 9 & 12 & \\
\hline & Respiratory Droplets & 147 & 161 & \\
\hline & More than one option & 14 & 23 & \\
\hline \multirow{3}{*}{$\begin{array}{l}\text { Do you think COVID } 19 \text { pandemic will } \\
\text { be controlled eventually? }\end{array}$} & Yes & 150 & 175 & \multirow{3}{*}{.744} \\
\hline & No & 16 & 17 & \\
\hline & Maybe & 38 & 41 & \\
\hline \multirow{3}{*}{$\begin{array}{l}\text { Have you avoided social events due to } \\
\text { current pandemic? }\end{array}$} & Yes & 164 & 190 & \multirow{3}{*}{.740} \\
\hline & No & 23 & 22 & \\
\hline & Sometimes & 17 & 21 & \\
\hline \multirow{3}{*}{$\begin{array}{l}\text { Do you wish to inculcate preventive } \\
\text { practices in your routine life post } \\
\text { CO19VID 19? }\end{array}$} & Yes & 158 & 177 & \multirow{3}{*}{.774} \\
\hline & No & 25 & 27 & \\
\hline & Unsure & 21 & 29 & \\
\hline \multirow{4}{*}{$\begin{array}{l}\text { Type of services preferred during hospital } \\
\text { visiting in time of pandemic }\end{array}$} & General Health Services & 44 & 53 & \multirow{4}{*}{.597} \\
\hline & Dental Services & 80 & 101 & \\
\hline & Both & 48 & 43 & \\
\hline & None & 32 & 36 & \\
\hline \multirow{2}{*}{$\begin{array}{l}\text { Awareness about COVID- } 19 \text { norms } \\
\text { violation }\end{array}$} & Yes & 92 & 90 & \multirow{2}{*}{.171} \\
\hline & No & 112 & 143 & \\
\hline
\end{tabular}


Upendra Singh Bhadauria, Bharathi Purohit et al.

\begin{tabular}{|c|c|c|c|c|}
\hline \multirow{3}{*}{$\begin{array}{l}\text { Deterioration in oral health during } \\
\text { lockdown and COVID- } 19 \text { pandemic }\end{array}$} & Yes & 42 & 49 & \multirow{3}{*}{.882} \\
\hline & No & 137 & 159 & \\
\hline & Maybe & 25 & 25 & \\
\hline \multirow{3}{*}{$\begin{array}{l}\text { Anxiety signs like numbness/tingling, } \\
\text { dizziness, nervousness before visiting a } \\
\text { dental centre }\end{array}$} & Yes & 19 & 20 & \multirow{3}{*}{.617} \\
\hline & No & 179 & 202 & \\
\hline & Maybe & 6 & 11 & \\
\hline \multirow{3}{*}{$\begin{array}{l}\text { Concerns about safety measures visiting } \\
\text { the dental centre during COVID } 19 \\
\text { pandemic }\end{array}$} & Yes & 117 & 124 & \multirow{3}{*}{.498} \\
\hline & No & 70 & 81 & \\
\hline & Maybe & 17 & 28 & \\
\hline \multirow{5}{*}{$\begin{array}{l}\text { If yes, most concernedaspect before } \\
\text { visiting a dental centre }\end{array}$} & Hygiene/ Cleanliness & 64 & 61 & \multirow{5}{*}{$\begin{array}{l}.05^{*} \\
(\mathrm{~s})\end{array}$} \\
\hline & Large number of people & 25 & 33 & \\
\hline & Dental Treatment & 15 & 22 & \\
\hline & Spread of infection & 80 & 83 & \\
\hline & More than one options & 20 & 34 & \\
\hline \multirow{3}{*}{$\begin{array}{l}\text { Awareness of different methods of } \\
\text { registration at the dental centre }\end{array}$} & Yes & 126 & 164 & \multirow{3}{*}{.116} \\
\hline & No & 53 & 41 & \\
\hline & Maybe & 25 & 28 & \\
\hline \multirow{5}{*}{ If yes, preferred mode of registration } & Mobile Application & 52 & 67 & \multirow{5}{*}{.876} \\
\hline & On spot in queue & 27 & 30 & \\
\hline & Website of dental centre & 40 & 45 & \\
\hline & Telephonic/On call & 57 & 56 & \\
\hline & More than one options & 28 & 35 & \\
\hline \multirow{5}{*}{$\begin{array}{l}\text { Chief Complaint/ Reason for visiting the } \\
\text { dental centre }\end{array}$} & Routine OPD & 60 & 74 & \multirow{5}{*}{.106} \\
\hline & Emergency Treatment/Pain & 58 & 89 & \\
\hline & Trauma/ Fracture & 9 & 10 & \\
\hline & Follow up & 60 & 48 & \\
\hline & Any other & 17 & 12 & \\
\hline \multirow{3}{*}{$\begin{array}{l}\text { Do you think COVID infection can } \\
\text { spread during dental treatment? }\end{array}$} & Yes & 75 & 93 & \multirow{3}{*}{.705} \\
\hline & No & 47 & 47 & \\
\hline & Maybe & 82 & 93 & \\
\hline \multirow{3}{*}{$\begin{array}{l}\text { Do you think you can wait for long } \\
\text { duration during the dental treatment } \\
\text { procedures at dental centres? }\end{array}$} & Yes & 71 & 88 & \multirow{3}{*}{.576} \\
\hline & No & 88 & 89 & \\
\hline & Maybe & 45 & 56 & \\
\hline \multirow{3}{*}{$\begin{array}{l}\text { Do you think the PPE kits create } \\
\text { hindrance in communication during } \\
\text { dental procedure? }\end{array}$} & Yes & 39 & 48 & \multirow{3}{*}{.385} \\
\hline & No & 112 & 113 & \\
\hline & Maybe & 53 & 72 & \\
\hline \multirow{3}{*}{$\begin{array}{l}\text { Would you prefer your dental queries } \\
\text { being solved via phone as compared to } \\
\text { your visit at the dental centre? }\end{array}$} & Yes & 92 & 110 & \multirow{3}{*}{.448} \\
\hline & No & 66 & 63 & \\
\hline & Maybe & 46 & 60 & \\
\hline \multirow{2}{*}{$\begin{array}{l}\text { Do you feel teleconsultation can serve as } \\
\text { effective means of providing dental care } \\
\text { post COVID } 19 \text { ? }\end{array}$} & Yes & 138 & 143 & .274 \\
\hline & No & 66 & 90 & \\
\hline \multirow{3}{*}{$\begin{array}{l}\text { Do you plan to visit a dental centre for } \\
\text { routine dental treatment in near future? }\end{array}$} & Yes & 151 & 165 & \multirow{3}{*}{.709} \\
\hline & No & 11 & 16 & \\
\hline & Maybe & 42 & 52 & \\
\hline
\end{tabular}




\section{DISCUSSION}

The present study conducted was first of its kind in assessing the patient's outlook and their needs and demands for dental care in this new era during and after COVID 19 pandemic. Given the novelty, high transmissibility of the disease and dental treatment procedures generating aerosols; during this pandemic, alterations are and will be required to maintain a healthy environment for the patients and the dental team.

In the present study, patients gathered information regarding COVID 19 from multiple sources (Social media, Newspaper, Television, Government websites and Government's COVID-19 Aarogyasetu app). Television and social media were reported to be the common single point source of information related to COVID-19.Akalu $Y$ et al.(10), Lincoln Leehang Lau et al. (11) in their studies reported television and radio $(59.9 \%)$ as the major primary sources of information for COVID-19.

$72.3 \%$ of the patients in our study were aware of the primary symptoms of the COVID 19 infection and $70.5 \%$ reported respiratory droplets as the primary mode of transmission of the virus; a study conducted by Lincoln Leehang Lau et al.(11) also reported that coughing and sneezing were identified as a transmission route by $89.5 \%$ of respondents in their study. The awareness regarding COVID-19 infection in our study is mainly attributed to the widespread measures taken for health promotion and prevention of the pandemic in India.

Patients in the present study did not report any anxiety before visiting a dental centre. In contrast to our study findings, a systematic review and metaanalysis conducted by Nader Salari et al.,(12) revealed a prevalence of anxiety as $31.9 \%$ and depression as $33.7 \%$. They observed the prevalence in general population whereas we assessed the anxiety of patient before visiting a dental centre.

The psychological impact of COVID-19 pandemic in this study; however, was perceived in the safety concerns reported by the patients before visiting the dental centre. The spread of infection was reported as most concerning aspect of visiting the dental centre thus highlighting the need of strict implementations for outpatient department and advocates policy level changes.

In line with the COVID prevention norms, social distancing and avoiding large gathering patients of our study reported standing in a queue in hospitals as the least preferred method of registration at the dental centre. Registration via mobile phones and telephonic/ on-call were more preferred by the patients. This is in accordance with the guidelines by MoHFW and
Dental Council of India for dental patients planning to visit dental hospitals.

The dental treatment during this pandemic emphasized primarily on emergency/ urgent management of the dental diseases; in line with this statement majority of patients in the study too visited with a complaint of emergency treatment/pain; Routine OPD and follow up for previous dental treatment were the other two reasons reported for visiting the dental centre this could be due to the emerging and previous history of dental diseases among the study patients.

The dentist's personality and communication have been cited as crucial in providing satisfactory dental care.(13). The incorporation of strict infection control and sterilization measures more than ever the dental treatment procedures have and will undergo multiple changes. Screening before treatment procedures, personal protective equipment (PPE) and longer time duration will be the "New Normal. (14). Patients in our study did not feel that PPEs can create hindrance in communication during dental procedures; however, were not willing to wait for a longer duration during the dental treatment procedures at the dental centre. This can be attributed to the fact that the patients had not encountered the actual dental care at the dentist's chamber but dentist with the PPE visualization was a mere concept to them as seen in various social media platforms.

Technological advances provide humanity with new, previously unavailable options. Telemedicine in this regard is of critical importance when one considers the consequences of health-care providers contracting COVID-19 as a result of direct exposure (15) or vice versa.

Suhani Ghai (16) in their study reported that teledentistry can complement the existing compromised dental system and can offer a novel solution to resume dental practice during the current pandemic. Patients in our study too preferred their queries being solved on the phone when compared to their visit at the dental centre and felt that teleconsultation can serve as an effective means of providing dental care postCOVID 19. Provisions for teleconsultation across all levels of health care systems can thus aid in delivering healthcare facilities at even remote locations of the country.

Gender differences among knowledge and dental service utilization were not reported except for the safety concerns in visiting a dental centre. In line with our findings the study conducted by Sonam Maheshwari et al., (17) also revealed no significant difference in knowledge scores of males and females for COVID-19.

The present study thus enlightens the perceptions and dental service utilization by the patients and 
highlights the avenues for appropriate, tailored strategies post-COVID to make dental care services more effective and equipped. The inclusion of patients from one centre due to pandemic although theoretically limits the generalizability of our study findings to other setting but can serve as a baseline in understanding the outlook of patients in general. This study can also aid in providing background information for determining the policy level changes in the routine treatment procedures following universal precautions and in all healthcare facilities required in this new era of dentistry.

Futuristically, patients in our study were not hesitant and planned to visit the dental centre for routine dental treatment, felt that COVID 19 pandemic will be controlled eventually and wished to include the preventive practices in routine life post-COVID 19 pandemic. The present study thus opens avenues for researches on perceptions and dental service utilization by patients in dental clinics, different levels of healthcare facilities' and in multicentre setting.

\section{CONCLUSION}

The study assessed the awareness, perception and dental service utilization by the study patients. The study findings reveal that the patients were aware of the pandemic and visited the dental centre primarily for emergency management. The patients had a positive outlook towards visiting the dental centre for treatment in near future, were willing to continue the preventive practices post COVID and highlighted the importance of teledentistry in the post-COVID-19 era.

\section{ACKNOWLEDGEMENT}

We thank all the patients for their active participation. We thank Mr. Ashish Kumar for the illustration development. We owe our gratitude to Mr. Kapil Kumar for the help in maintaining the stringent infection protocol for the study. We are also sincerely grateful to the registration counter staff of CDER, AIIMS New Delhi for streamlining the patient for participation in this study.

\section{REFERENCES}

1. Ministry of Health and Family Welfare [internet] [updated 2020 August 9; cited 2020 August 10]. Available from: https://www.mohfw.gov.in/.

2. World Health Organization [internet]. WHO Director-General's opening remarks at the media briefing on COVID-19 - [updated 2020 March 11; cited 2020 August 12]. Available from: http:// www.jpgmonline.com/contributors.asp.
3. Time [internet]. World Health Organization Declares COVID-19 a 'Pandemic.' Here's What That Means [updated 2020 March 11; cited 2020 August 12]. Available from: https://time. com/5791661/who-coronavirus-pandemicdeclaration/.

4. World Health Organization [internet]. Responding to COVID-19 - Learnings from Kerala [updated 2020 July 2; cited 2020 August 28]. Available from: https://www.who.int/india/news/featurestories/detail/responding-to-covid-19---learningsfrom-kerala.

5. Wikipedia [internet]. COVID-19 pandemic lockdown in India [updated 2020Septemberl;cited2020September1].Available from: https://en.wikipedia.org/wiki/COVID-19_ pandemic_lockdown_in_India.

6. The Hindu [internet]. Dental treatments may have to wait longer [updated2020June1;cited2020September2]. Available from https://www.thehindu.com/news/ national/karnataka/dental-treatments-may-haveto-wait-longer/article31726333.ece. Accessed on 29/08/2020.

7. Alharbi A, Alharbi S, Alqaidi S. Guidelines for dental care provision during the COVID-19 pandemic. Saudi Dent J. 2020; 32(4):181-86.

8. Roopa S, Rani MS. Questionnaire Designing for a Survey. J Ind Orthod Soc 2012; 46(4):273-77.

9. Lawsche, C.H. A quantitative approach to content validity. Personnel psychology 1975; 28:563-75.

10. Akalu Y, Ayelign B, Molla MD. Knowledge, Attitude and Practice Towards COVID-19 Among Chronic Disease Patients at Addis Zemen Hospital, Northwest Ethiopia. Infect Drug Resist. 2020; 13:1949-60.

11. Lincoln Leehang Lau, Natalee Hung, DarynJoyGo, JanselFerma, MiaChoi, Warren Dodd,Xiaolin Wei. Knowledge, attitudes and practices of COVID-19 among income-poor households in the Philippines: A cross-sectional study. Journal of Global Health 2020; 10(1): 1-11.

12. Salari, N., Hosseinian-Far, A., Jalali, R. et al. Prevalence of stress, anxiety, depression among the general population during the COVID-19 pandemic: a systematic review and metaanalysis. Global Health 2020; 16 (57): 1-11.

13. Holt VP. Patient satisfaction questionnaire-how to do them successfully. Dent Update. 2006; 33: $338-40$.

14. Edmund Profftt. What will be the new normal for the dental industry? British Dental Journal 2020; 228: 678-80.

15. Chauhan, Vivek\&Galwankar, Sagar\&Arquilla, Bonnie \& Garg, Manish \&Somma, Salvatore \& El-Menyar et al. Novel Coronavirus (COVID-19): Leveraging Telemedicine to Optimize Care While 
Minimizing Exposures and Viral Transmission. Journal of Emergencies Trauma and Shock. 2020; 13: 3-7.

16. Ghai S. Teledentistry during COVID-19 pandemic [published online ahead of print, 2020 Jun 16]. Diabetes MetabSyndr. 2020; 14(5):933-35.

17. Maheshwari S, Gupta PK, Sinha R, Rawat P. Knowledge, attitude, and practice towards coronavirus disease 2019 (COVID-19) among medical students: A cross-sectional study. J Acute Dis 2020; 9(3): 100-4.
Received: 30.11 .2020

Accepted for publication: 26,02.2021

Address for correspondence:

Dr. Harsh Priya

Associate Professor

Division of Public Health Dentistry

Centre for Dental Education and Research (CDER)

All India Institute of Medical Sciences, New Delhi-110029

Email id- drharshpriya@gmail.com

Contact Number- 9953428936 